\title{
Parasite infections (Trematoda, Digenea) of Sagitta friderici (Chaetognatha) from the southwestern Atlantic Ocean: prevalence and distribution
}

\author{
María C. Daponte ${ }^{1, *}$, Alicia A. Gil de Pertierra ${ }^{2}$, Mónica A. Palmieri ${ }^{1}$, \\ Margarita Ostrowski de Núñez ${ }^{2}$ \\ ${ }^{1}$ Laboratorio de Biología Marina, and ${ }^{2}$ Laboratorio de Helmintología, Depto. Biodiversidad y Biología Experimental, \\ Facultad de Ciencias Exactas y Naturales, Ciudad Universitaria, Pabellón II, Universidad de Buenos Aires, \\ C1428EHA Buenos Aires, Argentina
}

\begin{abstract}
The following chaetognaths were found in the Atlantic Ocean between 34 to $40^{\circ} \mathrm{S}$ and $52^{\circ} 20^{\prime}$ to $62^{\circ} 00^{\prime}$ W: Sagitta friderici, S. tasmanica, S. minima, S. gazellae, and S. enflata (in order of abundance). Of these, only $S$. friderici was parasitised by unencysted metacercariae of the families Derogenidae (Derogenes sp.), Hemiuridae (Ectenurus sp.) and Fellodistomidae (Monascus filiformis), and encysted metacercariae of Lepocreadiidae. The percentage of infection for each sampling station varied from 0.033 to 0.001 in August and from 0.02 to 0.001 in October 1996, with the highest values occurring at stations closer to the coast. The intensity of infection (worms per host) varied from 1 to 3 for Ectenurus sp. and was 1 for Derogenes sp., Monascus filiformis and Lepocreadiidae. Unencysted metacercariae were found in mature developmental stages of chaetognaths, whereas encysted ones occurred mainly in juveniles. The size and length of the ovaries of parasitised and unparasitised chaetognaths did not differ significantly. This is the first report of encysted Lepocreadiidae metacercariae and a progenetic metacercaria of Ectenurus sp. in Chaetognatha from the SW Atlantic Ocean.
\end{abstract}

KEY WORDS: Chaetognaths · Derogenes sp. $\cdot$ Ectenurus sp. $\cdot$ Monascus filiformis $\cdot$ Lepocreadiidae Argentine Sea $\cdot$ Zooplankton

\section{INTRODUCTION}

Many of the life cycles of helminths that parasitise pelagic fishes include copepods and/or chaetognaths as their intermediate hosts. Chaetognaths (arrow worms) constitute an important component of the marine zooplankton, both in coastal areas and in oceanic waters. These organisms may play a fundamental role in the transfer of energy from primary consumers to higher trophic levels, since they mainly feed on copepods (Reeve 1980, Feigenbaum \& Maris 1984, Stuart \& Verheye 1991, Casanova 1999) and are subsequently part of the diet of larval and adult fishes (Heydorn 1959, Cavalieri 1963, Szidat 1969, Terazaki \& Iwata 1983). Several chaetognath species perform diel vertical migrations (Gibbons 1994, Nishihama \& Hirakawa 1998, Besiktepe \& Unsal 2000), thus interacting with communities distrib- uted at different levels of the water column. Both the central position of chaetognaths in the food web and their migratory habits facilitate their role as intermediate hosts. Most of the epiplanktonic chaetognaths are transparent even after preservation, thus making it possible to observe species which parasitise them internally (Dollfus 1960, Alvariño 1965, Weinstein 1972, Nagasawa \& Marumo 1979, Øresland 1986, Martorelli \& Cremonte 1998). One of these species, Sagitta friderici, occurs frequently in neritic zones of the Atlantic Ocean, scattered along the western coast from $30^{\circ} \mathrm{N}$ to $49^{\circ} \mathrm{S}$ (McLelland 1980, 1984, Mazzoni 1990), whereas on the eastern coasts they have been reported from approximately $50^{\circ} \mathrm{N}$ to $36^{\circ} \mathrm{S}$ (Heydorn 1959, Pierrot-Bults \& Nair 1991). Despite their wide distribution, there is scarce information on the parasites of this species, most of which is limited to isolated observations from studies in other 
geographic areas other than those of our investigation (Furnestin 1957, Cavalieri 1963, Reimer et al. 1975). The present work examines the biodiversity, prevalence and intensity of infection of the helminths that parasitise $S$. friderici in the SW Atlantic Ocean.

\section{MATERIALS AND METHODS}

Chaetognaths were collected during 2 sampling surveys carried out in the Argentinean Sea (Fig. 1). The first survey was conducted in August 1996 in the El Rincón area $\left(38^{\circ} 30^{\prime}\right.$ to $40^{\circ} 30^{\prime} \mathrm{S}$ and $58^{\circ} 30^{\prime}$ to $61^{\circ} 15^{\prime} \mathrm{W}$ ) and included 18 stations that yielded 7212 specimens; the second, conducted in October 1996, at $34^{\circ}$ to $40^{\circ} \mathrm{S}$ and $52^{\circ} 20^{\prime}$ to $62^{\circ} 00^{\prime} \mathrm{W}$ covered 116 stations that yielded 2870 specimens. The latter survey covered 2 important breeding areas for fish: the Argentinean-Uruguayan common fishing zone (ZCPAU) to the north and El Rincón to the south. Plankton samples were fixed in $4 \%$ buffered formaldehyde in seawater. Total density $(D)$ of chaetognats in each sampling station was calculated as $D=$ ind. $\mathrm{m}^{-3}$. Chaetognaths were identified according to Casanova's (1999) criteria, and each specimen was also assigned to the following maturity stages (Daponte et al. 2004):

Stage 0 (juvenile): anterior and posterior fins developed, without ovaries or testes.

Stage I: ovaries undergoing development containing small oocytes, testes like fine tubes, some loose spermatocytes in the basal part of the tail, seminal vesicles absent.
Stage II: larger ovaries with oocytes of various sizes, spermatocytes occupying the coelom of the tail, seminal vesicles undergoing development, but still empty.

Stage III: ovaries fully developed containing mainly large oocytes, tail segment filled with, partially filled with or containing no spermatids. Seminal vesicles presented different degrees of filling or were broken by the expulsion of the sperm. Chaetognath size was measured (from the tip of the head to the end of the tail excluding the caudal fin) only from those stations where parasitised specimens were found. The sizes of all parasitised and unparasitised specimens from each stage were compared using the Wilcoxon signed-ranks test (Daniel 1978).

Metacercariae were removed from the bodies of chaetognaths using dissecting needles under a stereomicroscope. Entire worms were stained with Langeron's alcoholic chlorhydric carmine, differentiated in $1 \%$ hydrochloric ethanol, dehydrated through a gradual ethanol series, cleared in creosote, and mounted in Canada balsam. Some details were determined in specimens cleared in Amann's lactophenol. All measurements are given in micrometers, with the range followed by the mean in parentheses. Figures were drawn with the aid of a camera lucida. The specimens studied were deposited in the Colección Nacional de Parasitología of the Museo Argentino de Ciencias Naturales Bernardino Rivadavia (MACN-Pa), Buenos Aires, Argentina.

Prevalence $(P)$ and intensity of infection $(I)$ were determined for the August $\left(P_{\text {Aug }}, I_{\text {Aug }}\right)$ and October $\left(P_{\text {Oct }}\right.$ $\left.I_{\mathrm{Oct}}\right)$ surveys for each helminth species and the percentage of infection was calculated for each sampling station $\left(P_{\mathrm{Stn}}\right)$, according to Bush et al. (1997).

The following deposited material was analysed for comparison: (1) Derogenes parvus Szidat, 1950, MACN-Pa 4/1-4/3, from Eleginops maclovinus and MACN-Pa 4/6-4/7, from Urophycis brasiliensis, and (2) Ectenurus virgula MACN-Pa 64/164/5, from $U$. brasiliensis.

\section{RESULTS}

The following chaetognaths of the genus Sagitta were found: $S$. friderici, S. tasmanica, S. minima, S. gazellae and $S$. enflata (Table 1). Total density of chaetognaths at each sampling station is shown in Fig.1. The number of species diminished towards the south, and
Fig. 1. Location and density of the sampling stations of the surveys conducted in August $\left(38^{\circ} 30^{\prime}\right.$ to $40^{\circ} 30^{\prime} \mathrm{S}$ and $58^{\circ} 30^{\prime}$ to $61^{\circ} 15^{\prime} \mathrm{W}$ ) and October $\left(34^{\circ}\right.$ to $40^{\circ} \mathrm{S}$ and $52^{\circ} 20^{\prime}$ to $\left.62^{\circ} 00^{\prime} \mathrm{W}\right)$ 1996. ZCPAU: common Argentinean-Uruguayan fishing zone, ER: El Rincón, *, @: parasitised chaetognaths, $z^{*}, \mathrm{O}$ : unparasitised chaetognaths 
Table 1. Chaetognath species (Sagitta) from the SW Atlantic Ocean sampled in August $\left(38^{\circ} 30^{\prime}\right.$ to $40^{\circ} 30^{\prime} \mathrm{S}$ and $30^{\prime}$ to $61^{\circ} 15^{\prime} \mathrm{W}$ ) and October ( 34 to $40^{\circ} \mathrm{S}$ and $52^{\circ} 20^{\prime}$ to $62^{\circ} 00^{\prime} \mathrm{W}$ ) 1996. ZCPAU: common Argentinean-Uruguayan fishing zone; $D$ : density (ind. $\mathrm{m}^{-3}$ )

\begin{tabular}{|c|c|c|}
\hline$\overline{\text { (August) }}$ & (October) & $\begin{array}{l}\text { ZCPAU } \\
\text { (October) }\end{array}$ \\
\hline S. friderici & S. friderici & $\begin{array}{l}\text { S. enflata } \\
\text { S. friderici } \\
\text { S. gazellae } \\
\text { S. minima } \\
\text { S. tasmanica }\end{array}$ \\
\hline$D=1-34$ & $D=1-40$ & $D=1-98$ \\
\hline
\end{tabular}

only $S$. friderici was present in the El Rincón area. Of the 5 host species, only $S$. friderici was parasitised by trematodes. In the August survey, $44.44 \%$ of the stations presented parasitised specimens, compared with only $2.56 \%$ of stations in October. These specimens were distributed over 2 zones: ZCPAU $\left(36^{\circ} 30^{\prime}\right.$ to $\left.37^{\circ} 15^{\prime} \mathrm{S}\right)$ and El Rincón $\left(39^{\circ} \mathrm{S}\right)$, leaving intermediate, northern and southern areas where parasitised specimens were not found (Fig. 1). The density ranges in each area are shown in Table 1.

The most frequently infected maturity stages were stages II and III, followed by Stage I, whereas juveniles were not parasitised. The median sizes of parasitised and unparasitised chaetognaths of all stages did not differ significantly ( $p>0.05$, Table 2).

Metacercariae belonging to the families Derogenidae (Derogenes sp.), Hemiuridae (Ectenurus sp.), Fellodistomidae (Monascus filiformis), and Lepocreadiidae were found in Sagitta friderici (Table 3).

The $P_{\text {Stn }}$ values calculated for the total number of trematodes found (considering only those stations where parasitised specimens were found) varied from 0.033 to 0.001 in August and from 0.02 to 0.01 in October. The highest values were from stations closer to the coast and above $30 \mathrm{~m}$ depth. The values of $P$ and $I$ for August and October were calculated for each parasite and are indicated in the description of the specimens found.
Table 2. Sagitta friderici. Median size (mm) of the different maturity stages of parasitised (P) and non-parasitised (NP) specimens. Sample size (n) in parentheses; 0: juvenile

\begin{tabular}{|lcccc|}
\hline & \multicolumn{5}{c|}{ Maturity stage } & III \\
\cline { 2 - 5 } & \multirow{4}{*}{0} & I & II & \\
\hline P & Not found & $6.96(13)$ & $11.36(41)$ & $13.56(20)$ \\
NP & 4.91 & 7.76 & 11.38 & 13.24 \\
\hline
\end{tabular}

sucker $63 \mu \mathrm{m}$ long; pharynx well developed, $20 \mu \mathrm{m}$ long; ventral sucker near mid body region, $100 \mu \mathrm{m}$ long. Conspicuous papillae on ventral sucker, oral sucker and lateral areas of body (Fig. 3a). Intestinal caeca ending blindly near posterior extremity. Testes oblique. Ovary oval, post-testicular. Vitelline masses post-ovarian, oblique, globular to oval. Uterus not developed.

Infection site: coelomic cavity of the trunk (Fig. 2a),

$P_{\text {Aug }}=0.0003(\mathrm{n}=7212), I_{\text {Aug }}=1, P_{\text {Oct }}=0$.

Monascus filiformis, unencysted metacercaria (Figs. 2b \& 3b)

Family: Fellodistomidae Nicoll, 1909

Subfamily: Monascinae Dollfus, 1947

Measurements from 6 whole-mounted specimens, other morphological details from specimens mounted in Amann's lactophenol. Body oval, 284-368 (331) $\mu \mathrm{m}$ long, 136-184 (161) $\mu \mathrm{m}$ wide; tegument smooth; oral sucker 100-136 (118) $\mu \mathrm{m}$ long, 92-120 (108) $\mu \mathrm{m}$ wide; ventral sucker 44-68 (61) $\mu \mathrm{m}$ long, 60-72 (66) $\mu \mathrm{m}$ wide; pharynx 72-88 (80) $\mu \mathrm{m}$ long, $40 \mu \mathrm{m}$ wide. Primordia of testes and ovary in posterior part of body.

Infection site: anterior gut (Fig. 2b), $P_{\text {Aug }}=0.0001$ ( $\mathrm{n}=$ 7212), $I_{\text {Aug }}=1, P_{\text {Oct }}=0$.

Ectenurus sp., unencysted metacercaria (Figs. 2c \& 4) Family: Hemiuridae Looss, 1899

Subfamily: Dinurinae Looss, 1907

Measurements: based on 15 specimens mounted in Canada balsam. Details of terminal genitalia were observed in 4 specimens mounted in Amman's lactophenol. Body surface with plications (Fig. 4), 473-1008 (704) $\mu \mathrm{m}$ long, 145-309 (226) $\mu \mathrm{m}$ wide. Oral sucker terminal, 50-82 (69) $\mu \mathrm{m}$ in diameter. Pharynx 28-63 (51) $\mu \mathrm{m}$ long, 19-44 (34) $\mu \mathrm{m}$ wide. Intestinal

\section{DESCRIPTIONS}

Derogenes sp., unencysted metacercaria (Figs. 2a \& 3a)

Family: Derogenidae Nicoll, 1910

Subfamily: Derogeninae Nicoll, 1910

Measurements based on a single whole mounted specimen, some morphological details based on a specimen mounted and cleared in Amman's lactophenol. Body $300 \mu \mathrm{m}$ long, without ecsoma. Oral
Table 3. Parasites from Sagitta friderici in the surveys areas El Rincón (August and October 1996) and common Argentinean-Uruguayan fishing zone (ZCPAU) (October 1996). en: encysted metacercariae; un: unencysted metacercariae

\begin{tabular}{|c|c|c|}
\hline El Rincón & (October) & $\begin{array}{l}\text { ZCPAU } \\
\text { (October) }\end{array}$ \\
\hline \multicolumn{3}{|l|}{ Derogenes sp. (un) } \\
\hline Ectenurus sp. (un) & Ectenurus sp. (un) & \\
\hline \multicolumn{3}{|l|}{ Monascus filiformis (un) } \\
\hline Lepocreadiidae (en) & & Lepocreadiidae (en) \\
\hline
\end{tabular}



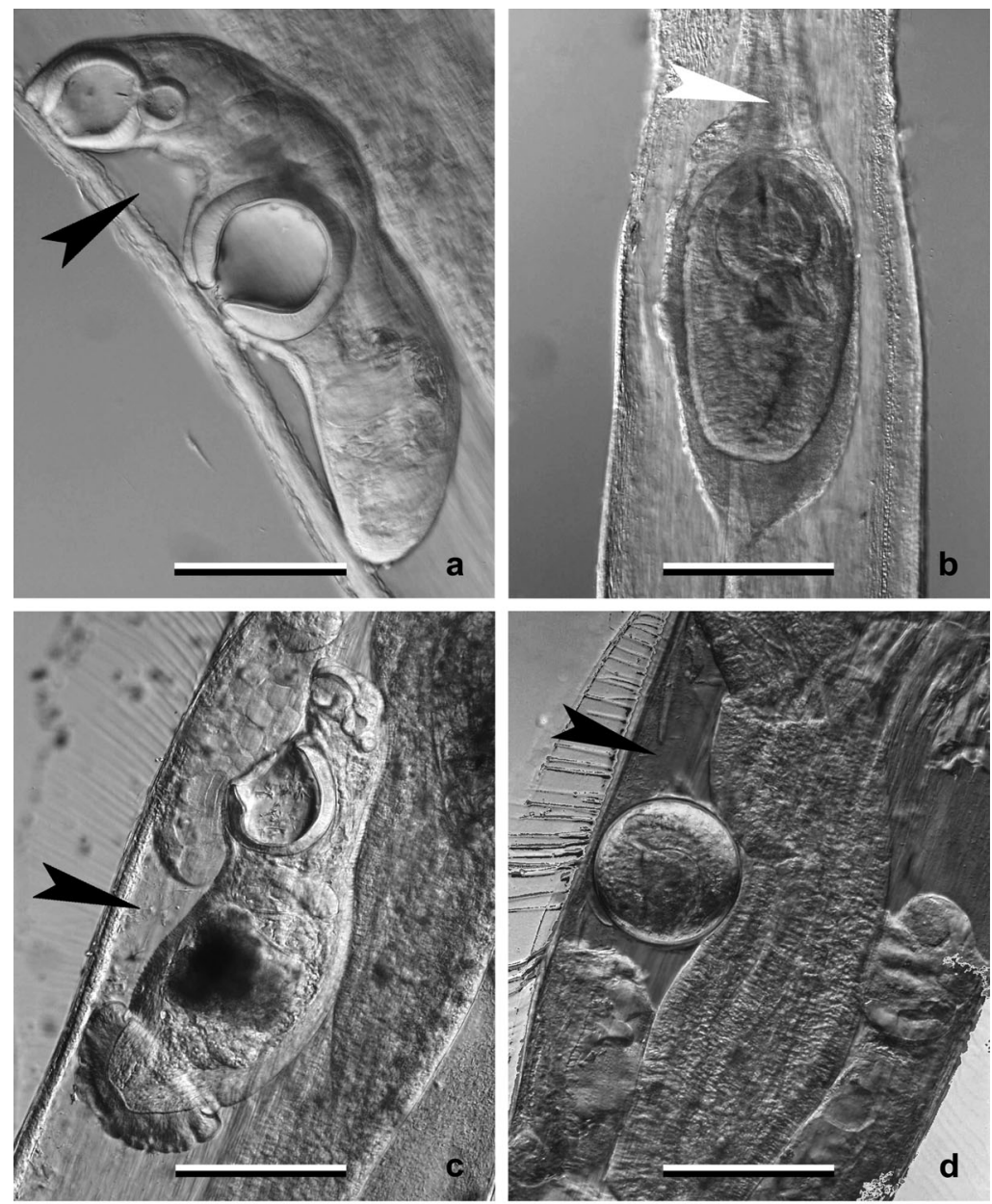

Fig. 2. Metacercaria from Sagitta friderici showing infection sites. (a) Derogenes sp. (b) Monascus filiformis. (c) Ectenurus sp. (d) Lepocreadiidae. Black arrowhead shows the coelomic cavity of the trunk. White arrowhead shows the anterior cavity of the gut. Scale bars $=$ (a) $100 \mu \mathrm{m}$; (b-d) $200 \mu \mathrm{m}$

caeca extending into ecsoma, when everted. Ventral sucker in first third of body 101-306 (185) $\mu \mathrm{m}$ long, 120-284 (173) $\mu \mathrm{m}$ wide. Ratio oral sucker:ventral sucker length: 1:2-3.7 (2.7), width: 1:2-3 (2.6). Ecsoma not completely developed, generally withdrawn (Fig. 4), when extended short, leafshaped (Fig. 2c). Testes oval, in tandem (Fig. 4a), oblique or parallel (Fig. 4b), sometimes overlapping, anterior testis 60-132 (88) $\mu \mathrm{m}$ long, 95-170 (128) $\mu \mathrm{m}$ wide; posterior testis 54-120 (80) $\mu \mathrm{m}$ long, 107-154 (134) $\mu \mathrm{m}$ wide. Ovary oval, posterior to testes, 54-120 (83) $\mu \mathrm{m}$ long, 107-161 (139) $\mu \mathrm{m}$ wide. Uterus extending into ecsoma when everted. Vitellarium forming 7 thick tubular lobes. Excretory arms not united in forebody. Seminal vesicle post-acetabular, 44-158 (74) $\mu \mathrm{m}$ long, 25-110 (56) $\mu \mathrm{m}$ wide, divided into 2 sections. Pars prostatica connected to distal part of aglandular duct to seminal vesicle, at the level of posterior end of ventral sucker. Eleven specimens with few to numerous eggs, 14.2-22.1 (19.2) $\mu \mathrm{m}$ long, 7.9-12.6 (10.8) $\mu \mathrm{m}$ wide.

Infection site: coelomic cavity of the trunk (Fig. 2c), $P_{\text {Aug }}=0.008(\mathrm{n}=7212)$, $I_{\text {Aug }}=1.31(1$ to 3$), P_{\text {Oct }}=0.0003(\mathrm{n}=$ 2870), $I_{\text {Oct }}=1$.

Family Lepocreadiidae, encysted metacercaria (Figs. 2d \& 5)

Observations based on 10 specimens cleared in Amman's lactophenol. Cysts 173-195 (176) $\mu \mathrm{m}$ long, 145-195 $\mu \mathrm{m}$
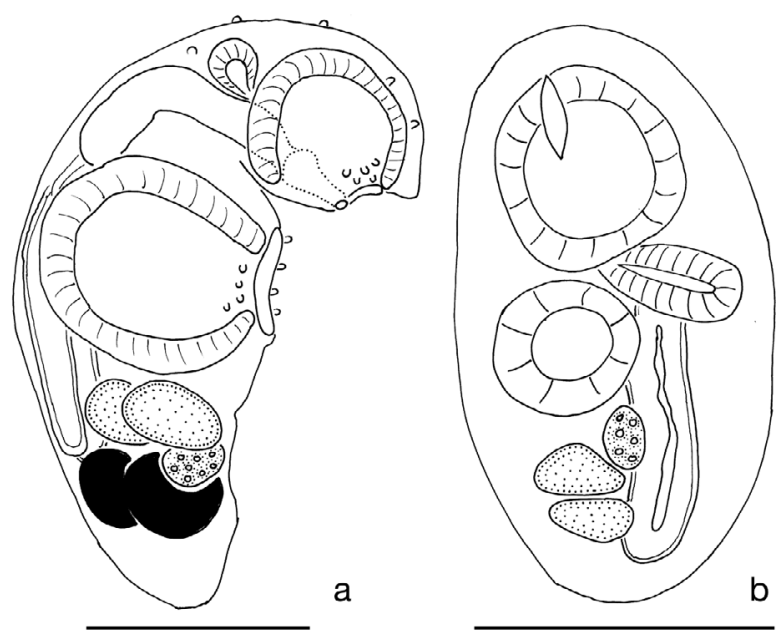

Fig. 3. Unencysted metacercariae from Sagitta friderici. (a) Derogenes sp., lateral view. (b) Monascus filiformis, ventral view. Scale bars = (a) $100 \mu \mathrm{m}$; (b) $200 \mu \mathrm{m}$ wide (Figs. 2d \& 5b). Tegument covered with spines up to posterior level of ventral sucker (Fig. 5a). Oral sucker 38-54 (46) $\mu \mathrm{m}$ long, 47-69 (59) $\mu \mathrm{m}$ wide; pharynx $41-57$ (52) $\mu \mathrm{m}$ long, 32 - 44 (39) $\mu \mathrm{m}$ wide; ventral sucker 41-63 (47) $\mu \mathrm{m}$ long, 41-63 (50) $\mu \mathrm{m}$ wide. Eyespot pigment dispersed at level of pharynx (Fig. 5). Oesophagus bifurcating immediately anterior to ventral sucker, intestinal caeca long, extending to near posterior end of the body (Fig. 5).

Infection site: coelomic cavity of the trunk (Fig. $2 \mathrm{~d}$ ), $P_{\text {Aug }}=$ $0.0007(\mathrm{n}=7212), I_{\text {Aug }}=1, P_{\text {Oct }}=0.0007(\mathrm{n}=2870), I_{\text {Oct }}=1$.

\section{DISCUSSION}

Metacercariae of Derogenes sp. parasitising Sagitta bipunctata (see Dawes 1958, Montero 1974) and Sagitta elegans (see Zaika \& Kolesnikov 1967) have 
previously been found in the Atlantic Ocean. Furnestin (1957) also found metacercariae in $S$. bipunctata, $S$. friderici and $S$. hexaptera that can be assigned to Derogenes sp. Two species of Derogenes are present in the South Atlantic, the cosmopolitan $D$. varicus (Müller, 1784), found in different fishes (Szi-
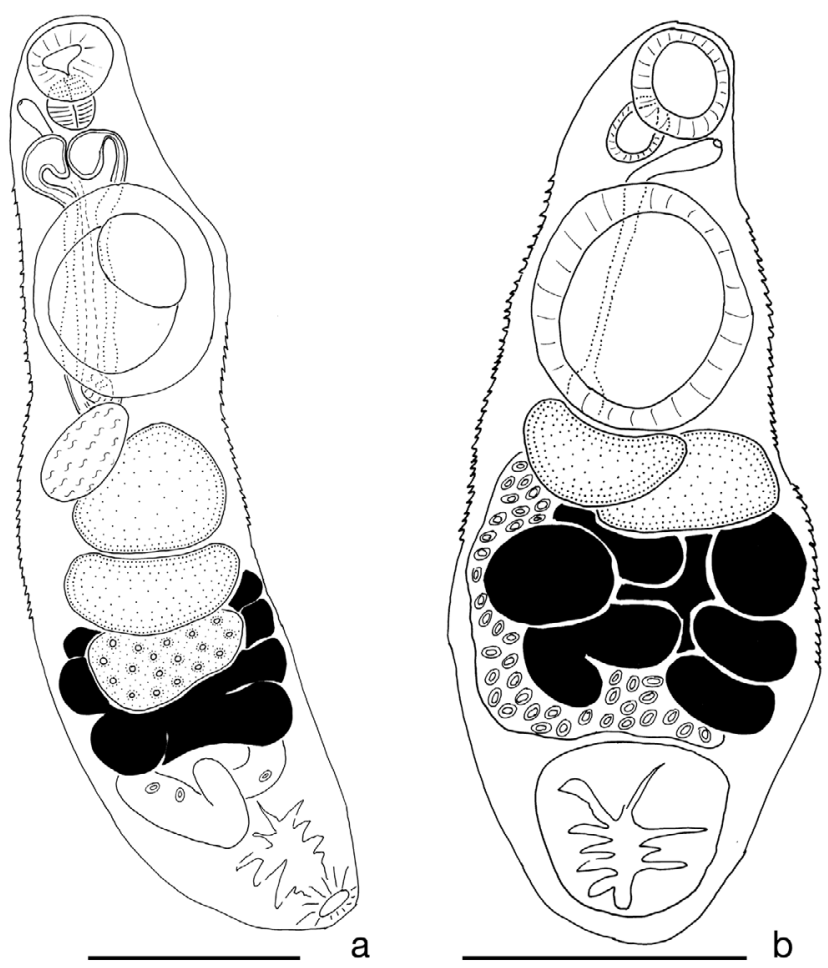

Fig. 4. Unencysted metacercariae from Sagitta friderici. (a) Ectenurus sp. showing testes in tandem, ventral view. (b) Ectenurus sp. showing the oblique position of testes and eggs inside the uterus, ventral view. Scale bars $=200 \mu \mathrm{m}$

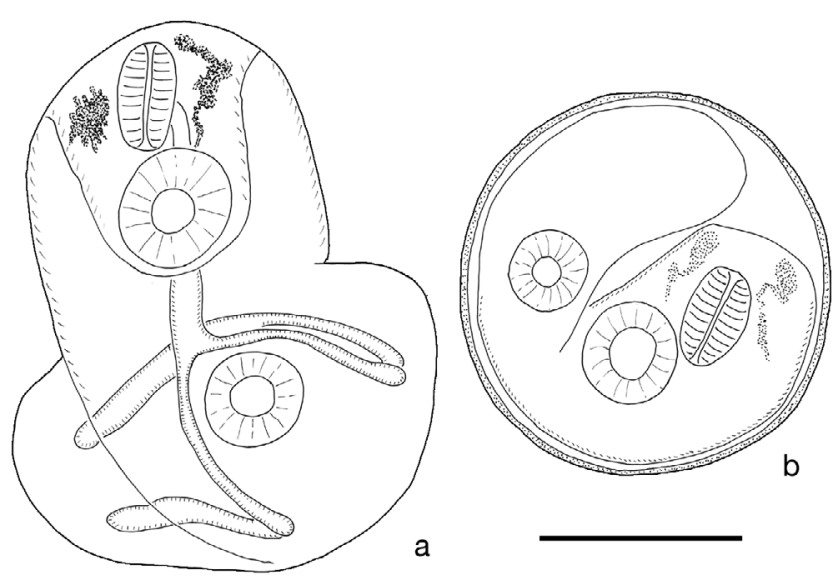

Fig. 5. Encysted metacercariae of Lepocreadiidae from Sagitta friderici. (a) Detail of the excysted metacercaria, ventral view. (b) Detail of cyst showing the metacercaria. Scale bar $=100 \mu \mathrm{m}$ dat 1961, Suriano \& Sutton 1981, Sardella \& Timi 1996), and D. parvus present in Eleginops maclovinus and Urophycis brasiliensis (see Szidat et al. 1950 and Szidat 1961). The immature metacercaria of Derogenes sp. could not be assigned to any particular species. Although not mentioned in previous descriptions (Suriano \& Sutton 1981), the tegumental papillae observed in the studied specimen (Fig. 3a) are similar to the 'hemispherical projections' mentioned by Køie (1979) in D. varicus. However, such papillae were not observed in the type material of $D$. parvus. The presence or absence of these projections may discriminate similar species of Derogenes in areas where both species occur.

Adults of Monascus filiformis were found in marine fishes of different families in the North Atlantic, the Gulf of Mexico and the Mediterranean Sea (Køie 1979). Metacercariae of this species were found in guts of Sagitta setosa in the western English Channel (Øresland 1986) as well as in the radial and annular channels of Hydromedusae and in the trunk cavity of Sagitta sp. from the South Atlantic Ocean (Girola et al. 1992, Martorelli \& Cremonte 1998). Cercariae were found in the clam Nucula nitidosa in waters of the western Kattegat (Køie 1979), and in N. oblique in the South Atlantic (Martorelli \& Cremonte 1998). The morphology of the $M$. filiformis found in the anterior gut of $S$. friderici agrees with the descriptions by Girola et al. (1992) and Martorelli \& Cremonte (1998). However, its smaller size probably reflects incomplete development. The finding of unencysted metacercariae in $S$. friderici supports the existence of the life cycle pattern proposed by Martorelli \& Cremonte (1998) in which $N$. oblique acts as a first intermediate host, chaetognaths and medusae are the second intermediate hosts and the final host, Trachurus lathami (Pisces: Carangidae), acquires the infection by eating infected chaetognaths and medusae.

A metacercaria of Ectenurus, probably E. virgulus according to Szidat (1961), who found this species in Urophycis brasiliensis, was reported by Jarling \& Kapp (1985) in a single specimen of Sagitta friderici from the Patagonian Shelf. These authors also found E. lepidus in higher prevalence in $S$. friderici, $S$. tasmanica, $S$. hexaptera and $S$. minima from the upwelling region off northwestern Africa. Chaetognaths studied by Jarling \& Kapp (1985) harboured other hemiurid metacercariae, which could not be identified. The difference between E. virgulus and E. lepidus is the presence of prostatic gland cells around the distal part of the male duct, occurring near the seminal vesicle in the former and around the anterior third of the male duct, near the sinus sac in the latter (Manter 1954). Differences in sucker ratios, egg size, shape of the vitellaria, and body measurements have been reported by Manter (1954), 
Manter \& Pritchard (1960) and Szidat (1961). The Ectenurus sp. specimens examined in the present study showed great variability in body size and in the position of the testes (Fig. 4), which are arranged either in tandem, parallel or oblique, and partially overlapped. The position of the testes is probably influenced by the state of contraction, and/or maturation and body size at maturation. There are also differences in sucker ratios ranging from 1:2.5 to 1:3.7. The specimens studied may belong to E. virgulus, (see Szidat 1961). However, the presence of E. lepidus in the same host, S. friderici, in the Atlantic Ocean near Africa (Jarling \& Kapp 1985), together with the observed morphological variability, indicate that more than one species may be involved.

Some specimens of Ectenurus sp. were gravid; because they were located inside the body cavity, they have to be considered progenetic metacercariae (Fig. 2c). The eggs would be released after the death of the intermediate host, or in the gut of a fish host, after ingestion of the infected chaetognath, indicating an abbreviated life cycle in the first case and a facultative life cycle in the latter. Poulin \& Cribb (2002) reviewed the examples of trematode species in which abbreviated life cycles have been reported, and proposed a hypothesis by which several factors (environmental instability, rare or missing host, developmental time, cannibalism, and latitudinal gradient) would promote a shortened life cycle. The 'rare or missing host hypothesis' explains shorter life cycles in which the definitive host undergoes seasonal migrations, fluctuations in abundance or very low predation rates (Poulin \& Cribb 2002). The low prevalence of Ectenurus sp. (0.0003 to 0.008$)$ and the absence of parasite-induced excess growth of chaetognaths, which made them more vulnerable to predation (Pearre 1979), might be responsible for the development of progenesis, as predation becomes a rare event.

Dollfus (1960) and Øresland (1986) reported encysted metacercariae of unknown families from chaetognaths as Adolescaria progastrica. This metacercaria is characterised by its developed gonads. Martorelli (1996) found an encysted metacercaria related to lepocreadiids in hydrozoan jellyfishes and ctenophorans of the southern Atlantic. In this metacercaria, tegumental spines cover the whole body surface, the intestine bifurcates shortly posterior to the pharynx and the oesophagus is short. The metacercaria from Sagitta friderici in the present study probably corresponds to a different species, since the tegumental spines reach the ventral sucker level, the intestine bifurcates immediately anterior to the ventral sucker, and the oesophagus is long (Fig. 5a). This is the first record of a lepocreadiid parasitising chaetognaths in the SW Atlantic.
Pearre (1976) reported differences between parasited and non-parasited specimens of Sagitta friderici and $S$. bipunctata. The parasitised hosts were larger and the ovary next to the parasite was shorter than normal. This phenomenon was also observed by Furnestin (1957) in S. bipunctata. The present analysis did not reveal significant differences in body size and ovary length between parasitised and unparasitised $S$. friderici (Table 2), although variations in the length of both sides of the ovary were observed in $1.8 \%$ of the unparasitised specimens collected at $38^{\circ} 28^{\prime} \mathrm{S}$, $57^{\circ} 41^{\prime} \mathrm{W}$ and $48 \mathrm{~m}$ depth (Daponte et al. 2004).

Chaetognaths become infected by metacercariae after eating free-swimming cercariae. Copepods, as the main prey item for chaetognaths (Alvariño 1965, Feigenbaum \& Maris 1984, Stuart \& Verheye 1991, Vega-Perez \& Liang 1992), can also constitute a source of infective metacercariae for their predators (Szidat 1969, Køie 1975, Martorelli \& Cremonte 1998).

Planktivorous fishes act as definitive hosts for parasites of chaetognaths, including the adults of the metacercariae reported herein. Adult digeneans of the families reported here were found in Merluccius hubbsi (e.g. Derogenes varicus), Parona signata (e.g. Lecithochirium microstomum), Micropogonias furnieri, Engraulis anchoita (e.g. L. microstomum), and Trachurus lathami (e.g. Monascus filiformis), Urophycis brasiliensis (e.g. Ectenurus virgula) (see Szidat 1961, Suriano \& Sutton 1981, Amato 1982, Sardella et al. 1995, Sardella \& Timi 1996, Martorelli \& Cremonte 1998, Timi et al. 1999).

The percentage of infection for each station $\left(P_{\mathrm{Stn}}\right)$ is dependent upon the sampling zone considered. In the El Rincón area, the range was 0.033 to 0.001 , from the inner to the median shelf, and zero in the outer shelf and at the slope boundary. In agreement with Alvariño (1965), who found a decrease of parasites in chaetognaths from neritic to oceanic areas, our results also indicate a decreasing percentage of infection by parasites from the inner to the outer shelf.

Considering the capture depth of different chaetognaths, we observed that those species captured below $90 \mathrm{~m}$ (Sagitta tasmanica, S. minima, S. gazellae, and $S$. enflata) were not parasitised. In $S$. friderici, although they were captured at depths between 13 and $90 \mathrm{~m}$, only the specimens collected above the $50 \mathrm{~m}$ isobath were parasitised. An analysis of the location of the sampling stations where parasitised chaetognaths were found showed that the locations were coincident with the presence of banks of bivalve molluscs (Mytilus edulis, Tagelus plebeius, Nucula puelcha, Brachiodontes rodriguezi, Amiantis purpurata) (see Cremonte 1999), some of which have been cited as primary hosts of trematodes in this region (Szidat 1963, Cremonte 1999, Cremonte et al. 2001). The migratory 
capacity of $S$. friderici would favour their encounter with cercariae released by bivalves. Chaetognaths may acquire cercariae directly in the benthic zone or by ingesting parasitised copepods in the pelagic area. The absence of banks of molluscs below $90 \mathrm{~m}$ may be a reason for the absence of parasites in the other chaetognath species considered, since these are generally located in the outer shelf and off the continental shelf, where such banks are absent.

\section{CONCLUSIONS}

In view of the present findings we conclude: (1) in the SW Atlantic, Sagitta friderici is an intermediate host of different trematode species. Chaetognath maturity Stages II and III are parasitised most frequently. Ectenurus sp. was the species with the highest prevalence and intensity of infection (double and triple). This is the first record of progenetic metacercariae of Ectenurus sp. from the SW Atlantic. (2) Derogenes sp. was found in mature chaetognaths (Stage III). Its prevalence was low and produced only single infections. Since Montero (1974) did not state the geographic location for his record of $D$. varicus from $S$. bipunctata, ours is the first record of Derogenes sp. parasitising $S$. friderici from the SW Atlantic. (3) Monascus filiformis had low prevalence and intensity of infection and was found only in mature chaetognaths (Stage III). The present work extends the distribution area of the metacercariae of $M$. filiformis parasitising $S$. friderici up to $40^{\circ} 15^{\prime} \mathrm{S}$ in the SW Atlantic. (4) The encysted metacercariae of Lepocreadiidae were more frequently found in Stage I specimens. prevalence was intermediate and its intensity of infection was one. This is the first record of metacercariae encysted in $S$. friderici from the southwestern Atlantic Ocean.

Acknowledgements. We thank the Instituto Nacional de Investigaciones y Desarrollo Pesquero (INDEP) and Dr. M. D. Viñas for providing the plankton samples. We are also grateful to Drs. S. Martorelli, R. Bray, and M. Køie for sending us their own work reprints. The research was supported by the Consejo Nacional de Investigaciones Científicas y Técnicas (Grant PIP No. 5974), and the Universidad de Buenos Aires-Ciencia y Técnica (Grant Nos. X004 and X025).

\section{LITERATURE CITED}

Alvariño A (1965) Chaetognaths. Oceanogr Mar Biol Annu Rev 3:115-194

Amato JFR (1982) Digenetic trematodes of percoid fishes of Florianopolis, Southern Brazil-Fellodistomidae, Monascidae, Diplangidae, Zoogonidae, and Waretrematidae with description of 2 new species. Rev Bras Biol 42:681-699
Besiktepe S, Unsal M (2000) Population structure, vertical distribution and diel migration of Sagitta setosa (Chaetognatha) in the south-western part of the Black Sea. J Plankton Res 22:669-683

Bush A, Lafferty K, Lotz M \& Shostak A (1997) Parasitology meets ecology on its own terms: Margolis et al. revisited. J Parasitol 83:575-583

Casanova JP (1999) Chaetognatha. In: Boltovskoy D (ed) South Atlantic zooplankton. Backhuys Publishers, Leyden, p 1353-1374

Cavalieri F (1963) Nota preliminar sobre Sagitta (Chaetognatha) del litoral Atlántico Argentino. Presencia de Sagitta friderici Ritter-Záhony en el plancton eulitoral. Physis 24:223-236

Cremonte F (1999) Estudio parasitológico de bivalvos que habitan ambientes marinos y mixohalinos en Argentina. $\mathrm{PhD}$ thesis, Universidad Nacional de La Plata

Cremonte F, Kroeck MA, Martorelli SR (2001) A new monorchiid cercaria (Digenea) parasitising the purple clam Amiantis purpurata (Bivalvia: Veneridae) in the southwest Atlantic Ocean, with notes on its gonadal effect. Folia Parasitol 47:217-223

Daniel WW (1978) Applied nonparametric statistics. Houghton Mifflin, Boston, MA

Daponte MC, Capitanio FL, Nahabedian DE, Viñas MD, Negri RM (2004) Sagitta friderici Ritter-Záhony (Chaetognatha) from South Atlantic waters: abundance, population structure, and life cycle. ICES J Mar Sci 61:680-686

Dawes B (1958) Sagitta as a host of larval trematodes, including a new and unique type of cercaria. Nature 182: 960-961

Dollfus RP (1960) Distomes des Chaetognathes. Bull Inst Pêches Marit Maroc 4:19-45.

Feigenbaun DL, Maris RC (1984) Feeding in the Chaetognatha. Oceanogr Mar Biol Annu Rev 22:343-392

Furnestin ML (1957) Chaetognathes et zooplanctoon du secteur Atlantique Morocain. Rev Trav Inst Pêches Marit 21:1-356

Gibbons M (1994) Diel vertical migration and feeding of Sagitta friderici and Sagitta tasmanica in the southern Benguela upwelling region, with a comment on the structure of the guild of primary carnivores. Mar Ecol Prog Ser 111:225-240

Girola CV, Martorelli SR, Sardella NH (1992) Presencia de metacercarias de Monascus filiformis (Digenea, Fellodistomidae) en hidromedusas del Atlántico Sur. Rev Chil Hist Nat 65:409-415

Heydorn AEF (1959) The Chaetognatha off the west coast of the Union of South Africa, July 1954-June 1995. Investig Rep Dep Comm Ind S Afr 36:1-56

Jarling Ch, Kapp H (1985) Infestation of Atlantic chaetognaths with helminths and ciliates. Dis Aquat Org 1:23-28

Køie M (1975) On the morphology and life-history of Opechona bacillaris (Molin, 1859) Looss, 1907 (Trematoda, Lepocreadiidae). Ophelia 13:63-86

Køie M (1979) On the morphology and life-history of Derogenes varicus (Müller, 1784) Loos, 1901 (Trematoda, Hemiuridae). Z Parasitenkd 59:67-78

Manter HW (1954) Some digenetic trematodes from fishes of New Zealand. Trans R Soc N Z 82:475-568

Manter HW, Pritchard M H (1960) Additonal hemiurid trematodes from Hawaiian fishes. Proc Helminthol Soc Wash 27: $165-180$

Martorelli SR (1996) First record of encysted metacercariae in hydrozoan jellyfishes and ctenophores of the southern Atlantic. J Parasitol 82:352-356

Martorelli SR, Cremonte F (1998) A proposed three-host life history of Monascus filiformis (Rudolphi, 1819) (Digenea: 
Fellodistomidae) in the southwest Atlantic Ocean. Can J Zool 76:1198-1203

Mazzoni H (1990) Chaetognatha del Mar Argentino. Ciclos estacionales de la distribución espacial y otros aspectos ecológicos. PhD dissertation, Universidad de Buenos Aires

McLelland JA (1980) Notes on the northern Gulf of Mexico occurrence of Sagitta friderici Ritter-Záhony (Chaetognata). Gulf Res Rep 6:343-348

McLelland JA (1984) Observations on chaetognath distributions in the northeastern Gulf of Mexico during the summer of 1974. Northeast Gulf Sci 7:45-59

Montero R (1974) Primer hallazgo de metacercarias parasitando Chaetognatha en el Atlántico sur. Rev Biol Urug 11:31-35

Nagasawa S, Marumo R (1979) Parasites of Chaetognatha in Suruga Bay, Japan. La Mer 17:127-136

Nishihama S, Hirakawa K (1998) Diel vertical migration of chaetognaths in the Tsushima Current area of the Japan Sea. Bull Jpn Sea Natl Fish Res Inst 48:71-83

Øresland V (1986) Parasites of the chaetognath Sagitta setosa in the western English Channel. Mar Biol 92:87-91

Pearre S Jr (1976) Gigantism and partial parasitic castration of Chaetognatha infected with larval trematodes. J Exp Mar Biol Ecol 53:503-512

Pearre S Jr (1979) Niche modification in Chaetognatha infected with larval trematodes (Digenea). Int Rev Gesamten Hydrobiol Hydrogr 64:193-206

Pierrot-Bults AC, Nair VR (1991) Distribution patterns in chaetognaths. In: Bone Q, Kapp H, Pierrot-Bults A C (eds) The biology of chaetognaths. Oxford University Press, New York, p 86-117

Poulin R, Cribb TH (2002) Trematode life cycles: short is sweet? Trends Parasitol 18:176-183

Reeve MR (1980) Comparative experimental studies on the feeding of chaetognaths and ctenophores. J Plankton Res 2:381-393

Reimer LW, Hnatiuk S, Rochner J (1975) Metacercarien in Planktontieren des mittleren Atlantik. Wiss Z Päd Inst Güstrow 2:239-258

Sardella NH, Timi JT (1996) Parasite communities of Merluccius hubbsi from the Argentinean-Uruguayan common fishing zone. Fish Res 27:81-88

Sardella NH, Etchegoin JA, Martorelli SR (1995) Las comu-

Editorial responsibility: Albert K. Sparks,

Seattle, Washington, USA nidades parasitarias de Micropogonias furnieri (corvina) en Argentina. Bol Inst Oceanogr Venez Univ Oriente 34: $41-47$

Stuart V, Verheye HM (1991) Diel migration and feeding patterns of the chaetognath, Sagitta friderici, off the west coast of South Africa. J Mar Res 49:493-515

Suriano DM, Sutton CA (1981) Contribución al conocimiento de la fauna parasitológica Argentina. VII. Digeneos de peces de la plataforma del Mar Argentino. Rev Mus La Plata Nueva Ser Secc Zool 12:261-271

Szidat L (1961) Versuch einer Zoogeographie des Südatlantik mit Hilfe von Leitparasiten der Meeresfische. Parasitol Schriftenr 13:1-96

Szidat L (1963) Los parásitos de los mitílidos y los daños por ellos causados. Neotropica 9:80-85

Szidat L (1969) Los parásitos de la 'Palometa' Parona signata (Jenyns, 1842) Berg, 1895, y su aplicación a problemas zoogeográficos del Atlántico sur. Neotrópica 15:125-131

Szidat L, Angelescu V, Siccardi E (1950) Dinurus breviductus Looss, 1907 (Trematoda. Fam. Hemiuridae). Agente causante de la 'Enfermedad de las manchas negras' de Clupea melanostoma Elg.1907 del Río de la Plata. Comun Mus Argent Cienc Nat 'Bernardino Rivadavia' Inst Nac Invest Cienc Nat 1:3-27

Terazaki M, Iwata M (1983) Feeding habits of chum salmon Oncorhynchus keta collected from Otsuchi Bay. Bull Jpn Soc Fish Oceanogr 49:1187-1193

Timi, JN, Martorelli SR, Sardella NH (1999) Digenetic trematodes parasitic on Engraulis anchoita (Pisces; Engraulidae) from Argentina and Uruguay. Folia Parasitol 46: 132-138

Vega-Perez LA, Liang TH (1992) Feeding of a pelagic chaetognath, Sagitta friderici Ritter-Záhony off Ubatuba region (Sao Paulo, Brazil). Bol Inst Oceanogr Sao Paulo 40: 93-100

Weinstein M (1972) Studies on the relationship between Sagitta elegans Verrill and its endoparasites in the southwestern Gulf of St. Lawrence. PhD dissertation, University of Montreal

Zaika VE, Kolesnikov AN (1967) On mass infection of Sagitta elegans arctica Aurivillius by sexually mature trematodes. Zool Zh 46:1121-1124 (in Russian)

Submitted: September 25, 2005; Accepted: March 18, 2006 Proofs received from author(s): July 18, 2006 